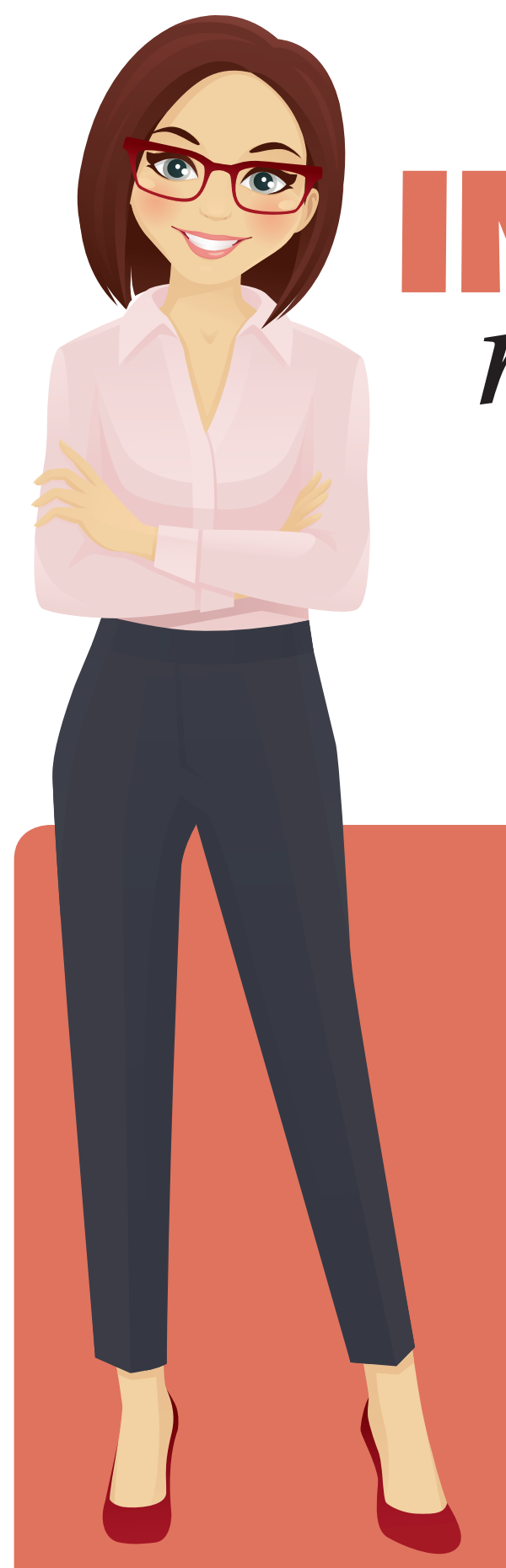

Ik heb een tweeling op de groep, Milan en Nolan.

'Leuk, twee jongens? Hoe oud zijn ze?'

Twee. Leuk ja, maar ze zetten met z'n tweeën de hele groep op stelten.

'Hoe krijgen ze dat voor elkaar?'

Ze spelen vaak samen, maar na een tijdje loopt het altijd uit de hand.

'Wat gebeurt er dan precies?'

Ze krijgen ruzie, gaan schreeuwen en gooien met dingen. De andere kinderen gaan dit nadoen.

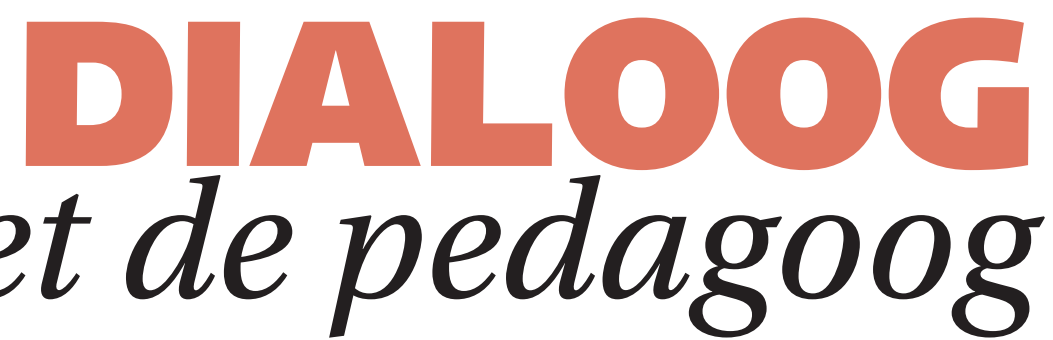

Pedagoog Inge van Rijn deelt ieder nummer een gesprek dat zij met een pedagogisch medewerker voerde. Deze maand: Moet die tweeling (niet) uit elkaar?

TEKST INGE VAN RIJN BEELD ISTOCK

'En wat doe jij als er zoiets gebeurt?'

Ik haal ze iedere keer uit elkaar. En thuis gebeurt hetzelfde. Ik heb de ouders voorgesteld om er één naar onze andere peutergroep te doen.

'Wat zeiden de ouders daarvan?'

Ze vinden de jongens nog net iets te klein.

'Daar hebben ze wel een punt. Voor hun ontwikkeling is het niet goed om tweelingen zo jong te scheiden.'

\section{Waarom niet?}

'Tweelingen zijn meestal sterk op elkaar gericht. Ze hebben elkaar nodig om zich veilig te voelen.'

Maar ze breken hier echt de boel af! 'Je kunt beginnen met goed kijken wanneer het spelen omslaat in ruzie. Zijn hier nog andere kinderen bij betrokken?'

Nee, altijd die twee.

'Wie neemt de leiding?'

Meestal Milan. Nolan volgt en doet er nog een schepje bovenop.

'En hoe doet hij dat dan precies?'

Als ze bijvoorbeeld met lego zitten te spelen, gooit Milan opeens alles om. Dan gaat Nolan staan springen, wordt het duwen en zo loopt het uit de hand. 'Oké, je hebt de verschillen tussen de twee jongens dus al scherp in beeld. Dat is heel goed; daar kunnen we ons op gaan richten.'

Dus in verschillende groepen zetten? 'Dat lijkt me toch te heftig voor ze. Maar je kunt ze ook binnen de groep stimuleren om wat losser van elkaar te komen.

\section{Hoe dan?}

'Laat de één eens meedoen met een activiteit in een kleine groep. Begeleid de ander in het spelen met een ander groepje. Zo leren ze los van elkaar contact maken met andere kinderen.'

En de rest van de dag?

'Zet ze bijvoorbeeld bij het eten aan twee verschillende tafels. Ze zien elkaar nog wel, maar zitten niet zo dicht op elkaar. En let ook op hoe je ze aanspreekt: als tweeling of als individu.'

Nu is het wel vaak: 'Milan en Nolan..' 'Dat is ook nog iets waar je wat mee kunt. Spreek ze apart aan en benader ze als individu. Observeer de verschillen en benoem die'

Maar als ze samen zitten te klieren? 'Dat gaan jullie nu juist voorkomen met deze aanpak!' 